\title{
Sport, Innovation and Strategic Management: A Systematic Literature Review
}

\author{
Anne Tjønndal ${ }^{\dagger}$ \\ Faculty of Social Science, Nord University
}

\begin{abstract}
Sport organizations adapt, renew and develop through creative and novel ideas. The various strategies for innovation applied by sport organizations hold the potential to radically change how we play, view and organize sport. In other words, through strategy, strategic management and innovation modern sport is shaped and improved. To date, limited scholarly attention has been given to strategy, strategic management and innovation in sport. However as the present review will demonstrate, sport innovation and strategic management of sports innovations are crucial for improvement of athletic performance. Furthermore, current research indicates that sport innovation can be a valuable tool to combat demanding challenges in modern sport, such as social exclusion. Therefore, innovation and strategic management needs specific attention within the sport sciences. The present paper attempts to provide more insight in the current body of research on sport innovation and strategic management. Finally, some recommendations for further research in this field is formulated.
\end{abstract}

Keywords: Innovation; sport; strategy; management; literature review.

*Author for correspondence:

$\dagger$. Institution: Faculty of Social Science, Nord University Address: Bodø, Norway Mobile phone: +004791791125

E-mail: anne.tjonndal@,nord.no

Note from the Editor: The article was accepted by Bruno Felix. 


\section{INTRODUCTION}

port organizations continue to adapt, renew and develop themselves through creative and novel ideas. The various strategies for innovation applied by sport organizations hold the potential to radically change how we play, view and organize sport. In other words, through strategy and innovation modern sport is. Strategy can here be thought of as patterns of actions employed by managers to position an organization for competitive advantage (Shilbury, 2011; Smith \& Stewart, 2010). In sport organizations, competitive advantages are often created through innovation. In this way, strategy and innovation are inherently linked within sports. Examples of strategic innovations in modern sport include the development of the race runner bike and the introduction of the fiberglass pole in Olympic high jumping (Balmer, Pleasence \& Nevill, 2012). Other examples of strategic innovation includes the increasing use of new technologies in sport, such as sensor monitoring in martial arts refereeing (Chi \& Res, 2005; Mukhopadhyay, 2014) or performance monitoring (Liebermann, Katz, Hughes, Bartlett, McClements \& Franks, 2002).

The need to foster innovation and strategy within sports itself may be greater than ever. Today, sport is confronted by long-term challenges such as practices of social exclusion, and discrimination based on factors such as gender, sexual orientation, race and ethnicity. A pressing challenge in elite and Olympic sport is the stagnation of athletic performance and world records, which have peaked in many sports during the last couple of years (Nevill \& Whyte, 2005; Nevill, Whyte, Holder \& Peyerbrune, 2007). Here, both strategy and innovation might be the solution needed for new record-breaking performances to take place (Balmer, Pleasence \& Nevill, 2012). To confront and solve challenges like these, sport organizations and federations need to develop strategies for innovation and implement strategic management of innovation processes. While innovation might be the solution to long-term challenges in modern sport, strategy and strategic management refers to the managerial process of formulating the pattern of actions needed for sport innovation to succeed (Sanderson \& Siegfried, 2003; Shilbury, 2011).

While innovation research has undergone a tremendous development and increased rapidly the last decades, there is little empirical research on strategy, innovation and entrepreneurship in sport (Tjønndal, 2016a). Although there has been an increase in sport innovation research in recent years, research in this area is still sparse. The same holds true for strategy research within the field of sport management (Slack, 1996; Shilbury, 2011). Strategy is central to all organizational life, and so it is unclear why this field of research has received so little. While there are some literature reviews of strategy research in sport management, such as Shilbury's article "Competition: The Heart and Soul of Sport Management" (2011), literature reviews on sport innovation has been sparse. Reviews of the innovation literature has constrained the focus to private and public sector organizations, neglecting sport from their frame of reference. This is unfortunate for at least two 
reasons. First, it limits the understanding of the role of innovation in strategic management of sport. Sport is a vital part of modern societies. Excluding this context narrows the understanding of innovation as a phenomenon, its antecedents and consequences. Second, it results in is little synthesized scholarly knowledge available to guide efforts to promote innovation through strategy and strategic management in sport. Although research on sport innovation has grown the last decade, research findings are scattered in different journals, across different communities, and has not been connected in a systematic way. In other words, there is lack of synthesized knowledge on innovation and strategy in the sports context. This paper addresses this gap.

As a method, systematic literature review stresses the importance of systematic account of the review process to ensure clarity and replicability (Tranfield, Denyer \& Smart, 2003). Guided by recommendations for analytical literature reviews (Jones \& Gatrell 2014), a systematic approach is taken to explore the literature and identify key themes, formulation a focus and selecting/deselecting themes, and analysing, interpreting and integrating literature. By conducting a systematic literature review, I examine the development of research on sport innovation, identify the key scientific contributions in this literature as well as important knowledge gaps, and outline a research agenda for the future. With this background, I pursue two objectives in this article:

1) to describe the development of research on sport innovation, and

2) to identify key themes to date and the challenges for future research on sport innovation, strategy.

\section{METHODS: PROCEDURES OF THE REVIEW}

In this literature review, I define sport innovation as any form of change, new idea or novelty in a sports context (Tjønndal,2016b). Viewing sport innovation from this perspective means taking a multifaceted and interdisciplinary approach to highlighting how innovation is created and made useful in the sports context. This includes, but is not limited to concepts such as product and service innovation, process innovation, organizational innovation, institutional innovation, policy innovation and social innovation. The following paper is a review of current literature on sport innovation, as defined here. Meaning that although the review includes different approaches to understanding sport innovation as a phenomenon, it excludes literature that does not specifically discuss innovation or deals with innovation terms and theories. This criterion is a clear limitation of the review since there might be a number of published articles discussing different forms of innovation in sport without actually calling it innovation. For instance, academic papers discussing organizational change within sports could be considered sport innovations without. The following article is a literature review on published articles with a clear definition of innovation. 


\section{Procedures}

Firstly, I conducted a comprehensive search for relevant scientific, peer-reviewed articles. I limited my review to include articles published in scientific journals only. This decision was made in order to ensure that only studies of high quality was included in the review. I selected four comprehensive and high quality databases as the core sources for retrieving journal articles for the review; 1) ISI Web of Science ${ }^{1}$, 2) Scopus, 3) SPORTDiscus and 4) PubMed. These databases are all generally thought to be high quality databases for academic journal articles. I chose to include four databases as sources for the review due to the immaturity of the field, as I expected articles about sport innovation to be published in a high variety of outlets. While PubMed primarily is a database for medical journal articles and research, this database often includes journal articles in the field of sports medicine. Hence, this database was included to retrieve articles published on innovations in sports medicine.

Defining a search string to identify articles discussion innovation in sport organisations proved to be a challenge as a substantial share of articles on appeared to mention 'innovation' in their abstracts or titles without actually discussing innovation as a theoretical or analytical subject. After careful deliberation, I decided to use a search string demanding that concepts representing innovation and concepts representing sport should be found in immediate vicinity. After initial exploration, I adopted the following search string: (innovation* near/5 sport) OR (innovation* near/5 physical activity) OR (entrepreneur* near/5 sport) OR (entrepreneur*near/5 physical activity) OR (sport innovation) OR (entrepreneurship*near/5 sport) OR (entrepreneurship*near/5 physical activity) (sport entrepreneurship) OR (sport AND innovation) OR (entrepreneurship AND sport) OR (strategy AND sport) OR (strategy AND sport innovation) OR (strategy*near/5 sport) OR (strategic management*near/5 sport). I searched in title, key words and abstracts, and specified the research to include journals within the areas of innovation, business, sport science, medicine, political science, sport management, sport sociology and psychology. Furthermore, I limited the search to articles in English language only. This search retrieved 128 articles for further consideration.

Secondly, I considered the abstracts of the identified articles for inclusion/exclusion using a set of criteria specified in line with the research objectives. The inclusion criteria were that innovation was a clearly identifiable object of study, and that the context of the study was sport and sport organizations. Hence, articles discussing innovation as a suggested implication or result of the study were not included in the review. After this process of

\footnotetext{
${ }^{1}$ Web of Science Core Collection
} 
reading and reviewing abstracts, 67 articles were included in accordance with the criteria and objectives of the review. Hence, the full text were retrieved of 67 articles. Third, a data-extraction form was developed to provide the basis for an analytical review (Jones and Gatrell 2014; Tranfield et al. 2003). The form included information about title, author, journal, publication year, research questions, theory, method, definitions, key findings and implications. The 67 articles were read and coded into the form. As result of this process, some articles were found not to fill the inclusion criteria after all and were excluded. Twentyfive articles were removed during the data-extraction process, reducing the sample to 42 . Fourth, I examined the reference lists of the selected articles to identify additional work that warranted inclusion in the review, but which due to the search string was not included in the initial search. This led to the inclusion of additionally 19 articles. Hence, the final body of work included in this review contains 61 journal publications, which arguably represents the body of research on sport innovation, meeting the above-specified criteria for inclusion.

Following the recommendations of Tranfield et al. (2003), I first provide a descriptive analysis of the field, and thereafter report the findings of a thematic analysis. Finally, based on the results from the review we develop a research agenda with specification of the needs for future research into public sector innovation.

\section{RESULTS AND DISCUSSION}

In this part of the article, I describe some key characteristics of the reviewed literature on sport innovation. A main trend is the increase in number of publications on sport innovation and strategy during the last six years. Furthermore, an in-depth analysis of the reviewed literature is presented.

\section{Increase in published literature on sport innovation and strategy}

Figure 1 demonstrates an increase in academic publications on sport innovation.. The first articles in the reviewed literature were published in the 1990s, but the research into this area has been limited until the early 2000s. This highlights the immaturity of sport innovation studies as an empirical field of research. However, there has been a take-off in the number of articles published on this topic the last 10 years. In fact, $90 \%$ of the articles covered by this literature review were published in 2005 or later. Thus, while the first academic interest in strategy and sport innovation appeared to have emerged during the $1990 \mathrm{~s}$, the field can nevertheless be said to be young and in a "take-off mode". This is also exemplified by that the increase in published articles since 2010. 


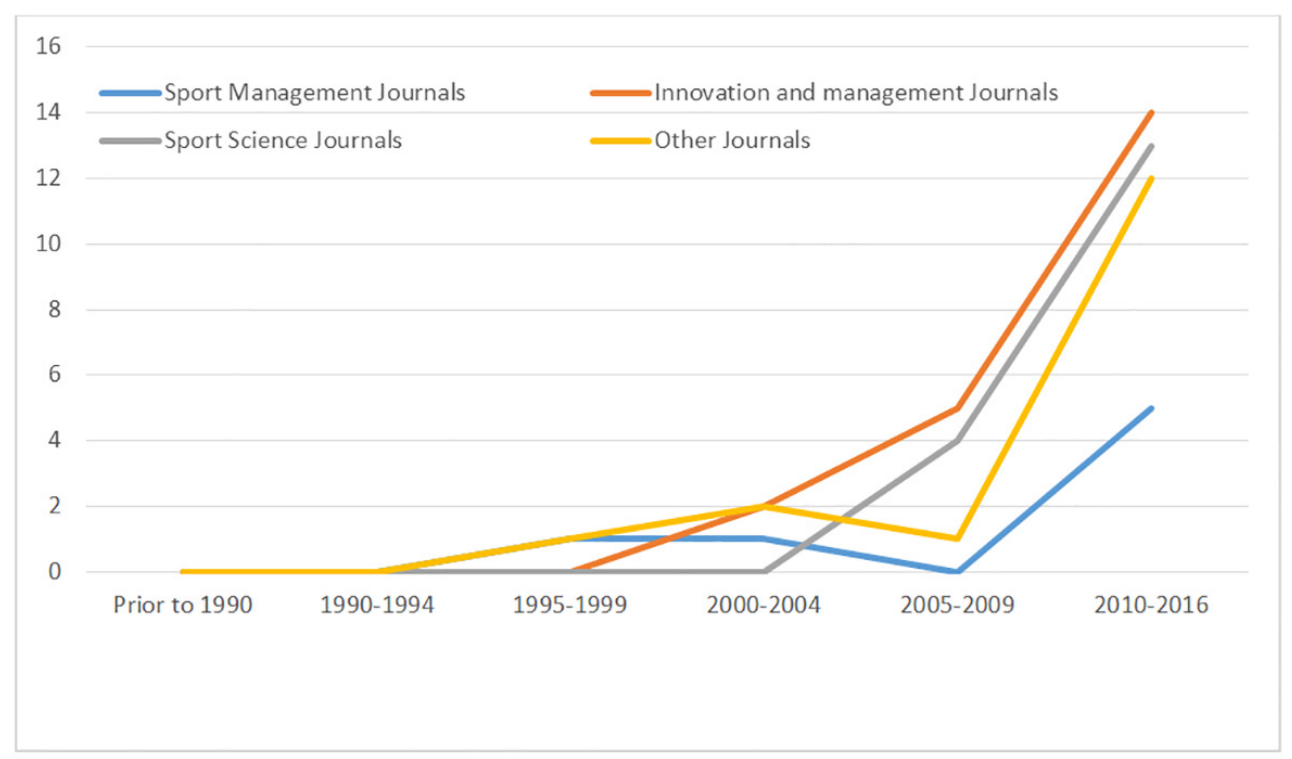

Figure 1. Number of publications on sport innovation by journal type and period

While most of the growth in the number of publication per year has been in journals devoted to sport management and related areas, sport innovation is now gaining momentum also in general sport science journals and journals dedicated to innovation and entrepreneurship research. Within the sport management field, Vanessa Ratten's work has contributed greatly to the advancement of research on sport entrepreneurship and innovation. Her key work centres on sport-based entrepreneurship (e.g. Ratten, 2011a; 2011b; 2012). In her article "Sport-based entrepreneurship: towards a new theory of entrepreneurship and sport management" (2011a) Ratten investigates the relationship between entrepreneurship and sport, and proposes a theory of entrepreneurship in sport management. Ratten has also argued for the social responsibility of sport management in her work on sport entrepreneurship (2010). Her pioneering work within the field of sport entrepreneurship and innovation has highlighted the importance and usefulness of the entrepreneurship perspective in sport management studies. In Ratten's latest work (2015) she explores a theoretical and conceptual understanding of athletes as entrepreneurs, demonstrating some of the complexity of research on sport entrepreneurship and strategy.

Substantial attention has been given to the role of strategy in innovations (e.g. Sundbo, 1998; Johnston \& Bate, 2013; Hoque, 2000). However, there research focusing on the relationship between strategy and innovation in sport. Studies of strategy and strategic management in sport underline that it is crucial for sport organizations to formulate strategies in order to anticipate changes and challenges (e.g. Thibault, Slack \& Hinings, 1993; Shilbury, Westerbeek, Quick \& Funk, 2009). As innovations often are changes with an intension of improvement or creation of value, it is somewhat puzzling that the connection between strategy, strategic management and innovation has not been made to a larger degree. Strategy and strategic management as means of 
anticipating the changes innovation brings is an under-explored phenomenon in studies of sport innovation.

Table 1 below shows an overview over the different types of sport science journals that have published articles on sport innovation since the 1990s. Together, sport science journals have published $32.8 \%$ of all articles covered in this review. Not surprisingly, journals dedicated to sport management has published the most number of articles on sport innovation $(n=9)$. The fact that sport management journals have shown the most interest in publishing scientific articles on this topic is most likely related to the history and tradition of innovation and strategy research and theory (e.g. Fagerberg, 2013; Scumpeter, 1942; 1983). Special issues of academic journals on sport strategy, entrepreneurship and innovation such as this one, is a further example of the increasing interest on this topic within sport management research.

\begin{tabular}{lcc}
\hline Journal type & Number of articles & Share of articles \\
\hline Sport History & 2 & $3.3 \%$ \\
Sport Sociology & 3 & $5 \%$ \\
Sport Management & 9 & $14.7 \%$ \\
Sport Medicine & 4 & $6.6 \%$ \\
General Sport Science Journals & 2 & $3.3 \%$ \\
Total publications within sport science journals & 20 & $32.8 \%$ \\
\hline
\end{tabular}

Table 1. Distribution - sport science journals

Looking beyond sport science journals, academic journals in other fields have also published several articles on sport innovation. Among scientific journals outside of the sport sciences, the trend is clear: management and innovation journals possess a clear majority in regards to the number of articles published on sport innovation $(\mathrm{n}=23)$. In total, articles published in management and innovation journals make up $37.7 \%$ of the total number of articles included in the reviewed literature (Table 2).

\begin{tabular}{lcc}
\hline Journal type & Number of articles & Share of articles \\
\hline Others & 7 & $11.4 \%$ \\
Psychology journals & 2 & $3.3 \%$ \\
Media studies & 3 & $5 \%$ \\
Sociology journals & 6 & $10 \%$ \\
Management and innovation journals & 23 & $37.7 \%$ \\
Total publications within sport science journals & 41 & $67.2 \%$ \\
\hline
\end{tabular}

Table 2. Distribution among other scientific fields 


\section{Quality of sport innovation publications}

One way to assess the quality of the research on innovation in the public sector is to examine the journals were the articles are published. For such purposes, I used the Norwegian Centre for Research Data (NSD) journal ranking system, which categorizes journals in two levels where the best quality journals are at level 2 .

A categorisation of the published articles according to journal level shows that $22.2 \%$ of the articles covered by this review were published in journals at level 2 in the NSD journal ranking system. Hence, a comparably large share of this literature was published in high-ranking journals. These articles in particular contain high-quality insight - as deemed by scholarly peers - into innovation in the sports sector. $13.4 \%$ of the articles in the reviewed literature was not published in academic journals ranked by The Norwegian Centre for Research Data, meaning it is hard to determine the quality of these publications on sport innovation.

\section{Type of studies}

In order to identify some key issues and topics for future research on sport innovation, I analysed what types of studies the articles in the reviewed literature consisted of. Taking a closer look at the literature, the published articles consisted of both empirical and theoretical papers. Among the articles reviewed here, $57.4 \%(n=35)$ were empirical papers, while $42.6 \%(n=26)$ were theoretical. Table 3 provides an overview of the types of studies that the published articles consisted.

\begin{tabular}{lcc}
\hline Type of study & Number of articles & Share of articles \\
\hline Qualitative & 18 & $29.6 \%$ \\
Quantitative & 15 & $24.5 \%$ \\
Literature review & 2 & $3.3 \%$ \\
Total empirical papers & 35 & $57.4 \%$ \\
Total theoretical papers & 26 & $42.6 \%$ \\
\hline
\end{tabular}

Table 3. Types of sport innovation studies

Looking at table 3, the distribution between qualitative and quantitative studies among the empirical articles reviewed. Of the 35 empirical papers published on sport innovation, 18 are qualitative studies and 15 are quantitative studies. The qualitative studies includes fieldwork, interviews and narrative approaches to understanding sport innovation. While the quantitative papers mainly consist of surveys, descriptive statistics and regression analyses. Two of the articles included were other literature reviews. However, these were not literature reviews on sport innovation as a field of research. 


\section{Main themes of research on sport innovation and strategy}

In this part of the literature review, I move from describing the characteristics of the literature to analyzing the themes, topics and content of the reviewed literature on sport innovation. Reading the published articles on sport innovation, some central topics appeared to be reoccurring. From an inductive research approach (Tjora, 2010) some main themes were determined in the reviewed literature. These main themes of research on sport innovation and strategy were then divided into six different categories: 1) Outcomes of strategic management and innovation, 2) innovation processes, 3) innovators and entrepreneurs, 4) innovation types, 5) innovation and strategy in sport organization and 6) antecedents of innovation and strategic management. These central topics are here illustrated in Figure 2.

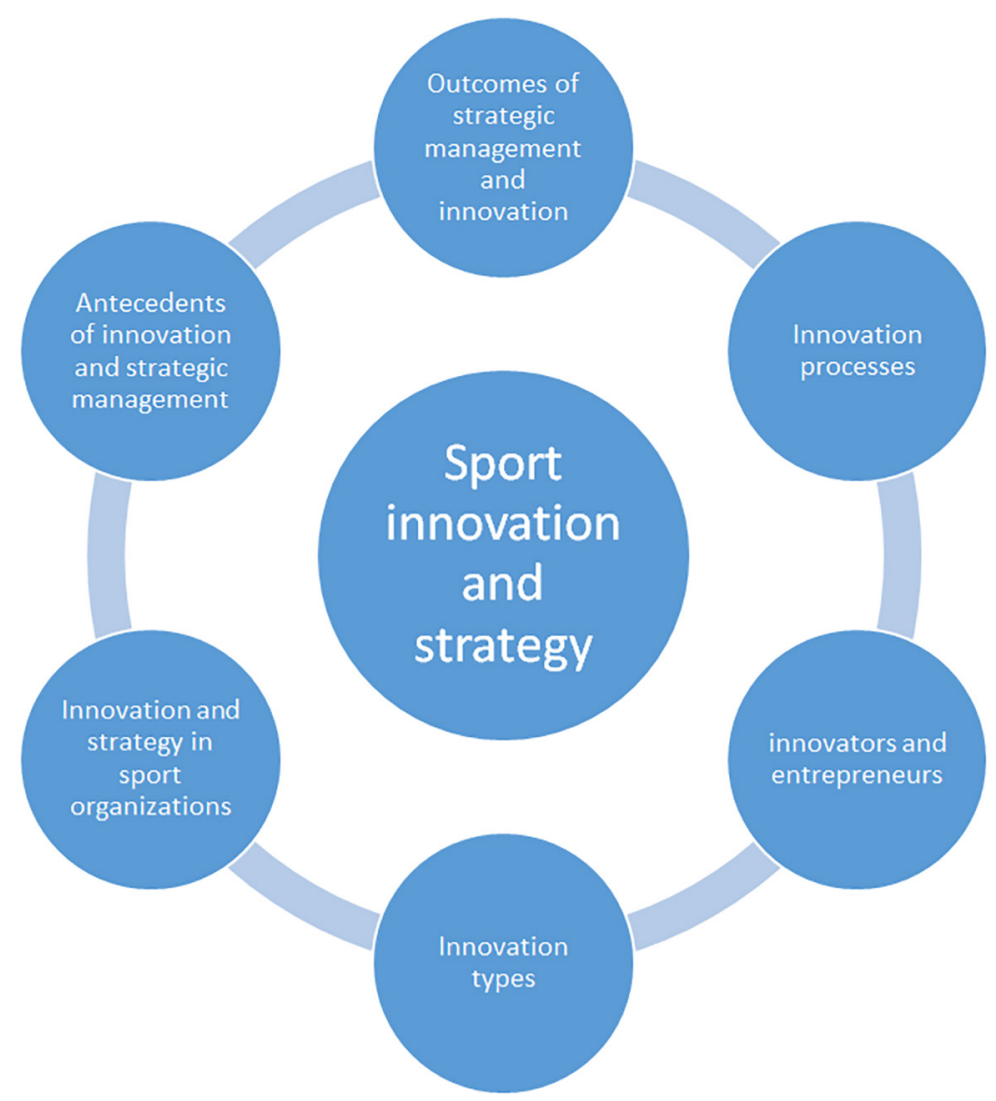

Figure 2. main article themes of the literature on sport innovation

Outcomes of strategic management and innovation includes articles that focuses on the "end result' of strategies for sport innovation. This includes journal articles discussing the development of new products within the sport industry, such as van der Woude, de Groot and Janssen's (2006) article on the development of manual wheelchairs and its impact on the health and physical activity of users. Studies of new technological and technical advancements in sport can also be categorized 
as outcomes of strategic management and innovation. Here, an example is Balmer, Pleasence and Nevill's (2012) work on the impact of technological and technical innovation strategies in Olympic performance. In their article, Balmer, Pleasence and Nevill discuss post-war men's Olympic performance in jumping events ${ }^{2}$ to determine whether performance has plateaued and to assess the impact of technological and technical innovation strategies in these sports over time. Here, the authors argue that in all four Olympic jumping events, further general growth in performance will need to rely on technological or technical innovation strategies (Balmer, Pleasence and Nevill, 2012). In similar studies, Nevill and Whyte (2005) has discussed limitations to world running records, and limitations to swimming world records (Nevill, Whyte, Holder \& Peyerbrune, 2007). Lastly, this category of research on sport innovation and strategy includes studies investigating new models of organizing and structuring sport activities. An example from the reviewed literature here is Pantzar and Shove's (2010) study of Nordic walking. In their work, Pantzar and Shove (2010) demonstrates how innovation and strategy in sport is an on-going process involving managers, manufacturers and consumers. Pantzar and Shove (2010) utilizes Nordic Walking as an empirical example examine how Nordic Walking has expanded and changed during the last decade.

The second category, innovation processes, describes articles in the reviewed literature that examines sport innovation strategies as dynamic, on-going processes. This category within the reviewed literature varies greatly in context and topic. An example is English's (2014) study of the diffusion of twitter-usage among sports journalists, where he maps the development of how sports journalists in different countries uses the social media site Twitter in their daily work. English analyses when and why sports journalists adopts the use of Twitter. In a different study of innovation processes, Fredberg and Piller (2011) studies the impact of tie strength in customer relationships for innovation in the sports industry. In their paper, Fredberg and Piller (2011) concludes that both strong and weak customer ties can lead to innovation within the sports industry, using the brand Adidas as an example of how strong ties can support significant innovation strategies. Another example within this category is Hoeber \& Hoeber's (2012) study of technological innovation in community sport organizations. This study explores different strategy stages of innovation in community sport organizations, as well as highlighting leadership commitment, pro-innovation characteristics, organizational capacity and a simple organizational design as key determinants for the implementation of strategy and innovation in sport organizations.

In regards to the third category of studies, innovators and entrepreneurs, there are many diverse examples of articles on this topic in the reviewed literature. Among them is Esson's (2015) qualitative study of the entrepreneurial ventures of young Ghanaian football players. Esson's (2015) study demonstrates how young male Ghanaians invest their time and efforts in developing

${ }^{2}$ The pole vault, long jump, high jump and triple jump events 
themselves as football entrepreneurs by becoming football club owners or attempting to profit from the migration potential of younger players. Most of the articles within this category highlight the micro level of sport innovation, looking specifically at the individuals involved in developing new ideas in modern sport, such as Cohen \& Peachey's (2015) article on social entrepreneurs within a sport-for-development context. Cohen \& Peachy (2015) examined the impact of a sport-fordevelopment initiative, Street Soccer USA, in order to understand how some of the most successful participants develops motivation towards becoming a cause champion and a social entrepreneur. Another key article within this category of the reviewed literature is Coontz (2011) study of sport bookmakers as entrepreneurs. This article is based on interviews with 47 sport bookmakers. The analysis of these interviews focuses on the social, organizational and occupational features of sport bookmakers as entrepreneurs. Lastly, Ratten (2015) has highlighted how the role of athletes as entrepreneurs is an under-explored area of the entrepreneurship and sport management literature. Her article bridges the gap between social capital theory, psychology theory and sport entrepreneurship theory to demonstrate how athletes can become entrepreneurs through their social, emotional and leadership abilities.

The fourth category of articles in this review I have called 'Innovation types'. Innovation types refers to articles concerned with describing different types of innovation strategies in the sports sector, such as Duret and Angue's (2015) article on the differences between technical and social innovation in outdoor sports. In their paper, Duret \& Angue (2015) argue that social and technical innovations can appear as both independent of each other, and as intertwined in the same innovation process. The authors underline a main difference between the two sport innovation types. Describing technical innovation as aimed at addressing individual issues experienced by small groups of people, while social innovations are intended to address a larger social issue within outdoor sports. Furthermore, these different sport innovation types require different strategies and strategic management in their implantation phases. Hyysalo's (2009) article on user innovation and everyday practices in the sports industry is another example of this category. Hyysalo describes user innovation in the sports industry micro-adaptions and micro-innovations produced by athletes and sport practitioners themselves. Hyysalo utilizes kayaking and kayakers to explore how athletes make adoptions and create innovation in their sporting activities. A specific innovation type that has received the majority of empirical attention so far is research on strategies for technological innovation in sport. Lastly, Ringuet-Riot, Hahn \& James (2013) provides a systematic model for sport technology innovation in their work. Their work signifies the importance of identifying key stakeholders and contexts to facilitate technological innovation in sport.

The fifth category of article themes is "innovation and strategy in sport organizations". This category describes articles in the reviewed literature that examines strategies for innovation in 
sports organizations. These articles discuss strategy and innovation in sport organizations generally, such as Desbordes' (2002) article on the innovation phenomena in the sports equipment industry, or strategy and innovation in specific contexts within the sports sector, for instance, Nordin \& Svensson's (2007) study of the Swedish ski resort Åre. Desbordes (2002) argues that while some sectors, like skiing or yachting, focus on process innovations, other sectors, like snowboarding and mountain biking, focus on product innovations.

In addition to Nordin and Svensson's study (2007), another example of a case-specific study in this category of the literature is Danylchuk, Snelgrove \& Wood's (2015) article on organizational change in golf. Their paper develops an understanding of the success factors and challenges associated with implementing change initiatives aimed at increasing women's continued participation in golf. Their findings describe a process of innovations and strategies in response to political and functional pressures, a systematic effort to play and sell a new vision and the reasons behind the successful adoption by the members. Hoeber, Doherty, Hoeber \& Wolf (2015) has studied the nature of innovation in community sport organizations through semi-structured interviews. Their article on innovation strategies in sport organizations underlines the diversity of innovation strategies and strategic management pursued within community sport organizations. Their results indicated that within their sample of 42 sport organization, 188 different innovations could be identified.

The final category, "Antecedents of innovation and strategic management", includes studies that are concerned with factors influencing the innovation process and strategy management in sport. An example of studies within this category of the reviewed literature is Winand, Vos, Zintz \& Scheerder's (2013) article on determinants of service innovation in sports federations. Fuller, Jawecki \& Muhlbacher (2007) investigated innovation creation and strategy in online basketball communities, looking specifically on the consumer communities of basketball shoes. Their results indicates that in some cases, sporting goods consumers are highly creative and possess sufficient domain specific skills and motivation to develop new and innovative strategies for new basketball shoes. A final example of key works in this category is Hunter's (2010) paper on how scientific methods with their high emphasis on objectivity, reduction of bias, control and randomization, can act as barriers for sport innovation strategies, proposing a more creative and open approach to strategies for sport innovation and strategy.

Table 4 summarizes the analysis of the reviewed literature presented in this literature review. The full references to all of the articles included in this literature review can be found under the reference section of this paper. 
Table 4. Article examples from each thematic category of the reviewed literature on sport innovation and strategy

\begin{tabular}{lccc}
\hline Article theme & Example 1 & Example 2 & Example 3 \\
\hline $\begin{array}{l}\text { Outcomes of strategic } \\
\text { management and } \\
\text { innovation }\end{array}$ & $\begin{array}{c}\text { Balmer, Pleasence \& } \\
\text { Nevill (2012) }\end{array}$ & $\begin{array}{c}\text { Harun \& Salamuddin } \\
(2013)\end{array}$ & $\begin{array}{c}\text { van der Woude, de Groot } \\
\text { \& Janssen (2006) }\end{array}$ \\
\hline $\begin{array}{l}\text { Innovation processes } \\
\begin{array}{l}\text { Innovators and } \\
\text { entrepreneurs }\end{array}\end{array}$ & Fredberg \& Piller (2011) & $\begin{array}{c}\text { Goff, McCormick, \& } \\
\text { Tollison (2002) }\end{array}$ & Hoeber \& Hoeber (2012) \\
\hline $\begin{array}{l}\text { Innovation types } \\
\text { Ruten (2015) }\end{array}$ & Cohen \& Peachey (2015) & Coontz (2001) \\
\hline $\begin{array}{l}\text { Innovation and strategy in } \\
\text { sport organizations }\end{array}$ & $\begin{array}{c}\text { Danylchuk, Snelgrove \& } \\
\text { Wood (2015) }\end{array}$ & $\begin{array}{c}\text { Hoeber, Doherty, Hoeber } \\
\text { \& Wolfe (2015) }\end{array}$ & Newell \& Swan (1995) \\
\hline $\begin{array}{l}\text { Antecedents of innovation } \\
\text { and strategic management }\end{array}$ & $\begin{array}{c}\text { Fuller, Jawecki \& } \\
\text { Muhlbacher (2007) }\end{array}$ & Hunter (2010) & Liang (2013) \\
\hline
\end{tabular}

\section{CONCLUSIONS: PROSPECTS FOR FUTURE RESEARCH ON SPORT INNOVATION}

In the present literature review, I have tried to provide some key insights in regards to sport innovation and strategy as an academic field of research. By systematically analyzing the characteristics of the published articles this review demonstrates that sport innovation and strategies for sport innovation, is a new, emerging and immature field of research within the sport sciences. Even though four academic journal databases were included in the review process, only 61 published articles were included in the literature review. Secondly, the earliest article identified was not published until the beginning of the 1990s, which again underpins that sport innovation, is a field still in the early stages of development. Furthermore, as a field, sport innovation has become increasingly popular during the last ten years. It is during the last five years that the number of published articles on sport innovation has increased the most. However, there is a need for further research discussing the relationship between strategy and sport innovation, as well as the role of strategy in sport innovation processes.

Like innovation research in general (Hartley, 2013; McKeown, 2008), sport innovation research is scattered between different academic disciplines. The analysis of the characteristics of the literature indicates that sport innovation includes published articles within sport management, sport sociology, sport medicine, sport psychology and sport history. In other words, sport innovation is a multifaceted research field. This is perhaps not so surprising, seeing as innovation as a term is defined, adapted and used in a variety of different settings (Baregheh, Rowley \& Sambrook, 2009). This is also mirrored in the distribution among empirical and theoretical published articles on sport innovation and the distribution between different methodological approaches to understanding and measuring innovation. As the review demonstrates, there is an even distribution between qualitative 
and quantitative studies of sport innovation, as well as empirical and theoretical articles on the sport innovation phenomena.

It is within management and business that sport innovation has received the most empirical attention so far. While there are still limited studies on sport innovation from a sociological, historical and organizational perspective. For future research on sport innovation, it is important to take into account these perspectives on the innovation phenomena. While the development of new technologies, sporting equipment and products are important and contribute greatly to the advancement of modern sport, studies on topics such as drivers and barriers for sport innovation, social innovations in sport and effective leadership and management of sport innovation are underexamined. For future research projects, it will be important to investigate these perspectives on sport innovation, as well as new strategies for sport innovation and the implementation of strategic management of sport innovation.

\section{REFERENCES}

Avice, E. (2006). Health, sport and innovation. Science and Sports.

Balmer, N. Pleasence, P. \& Nevill, A. (2012). Evolution and revolution: Gauging the impact of technological and technical innovation on Olympic performance, Journal of Sports Sciences, $30: 11,1075-1083$

Baregheh A, Rowley J and Sambrook S (2009). Towards a multidisciplinary definition of innovation. Management Decision, vol. 47, issue 8: 1323-1339.

Boutroy, E., Vignal, B. \& Soule, B. (2015). Innovation theories applied to the outdoor sports sector: Panorama and perspectives. Society and Leisure, 38:3, 383-398.

Chi, E.H. \& Res, P.A. (2005). Introducing wearable force sensors in martial arts. IEEE Pervasive Computing, vol 4, issue 3: 47.53

Cohen, A. \& Peachey, J.W. (2015). The making of a social entrepreneur: from participant to cause champion within a sport-for-development context. Sport Management Review, 18, 111-125.

Coontz, P. (2001). Managing the action: sport bookmakers as entrepreneurs. Deviant Behavior, $22: 3,239-266$.

Corte, U. (2013). A Refinement of collaborative circles theory: Resource mobilization and innovation in an Emerging Sport. Social Psychology Quarterly, 76 (1), 25-51.

Danylchuk, K., Snelgrove, R. \& Wood, L. (2015). Managing women's participation in golf: a case study of organizational change. Leisure/Loisir, 39:1, 61-80.

Desbordes, M. (2001). Innovation management in the sports industry: Lessons from the Salomon case. European Sport Management Quarterly, 1(2), 124-149.

Desbordes, M. (2002). Empirical Analysis of the innovation phenomena in the sports equipment industry. Technology Analysis \& Strategic Management, 14:4, 481-498.

Dulakahoria, S. \& Jana, T. (2013). Mapping innovation growth in the sports industry through patent data mining. Journal of Intellectual Property Right, 18, 410-418. 
Duret, P. \& Angue, K. (2015). Two norms for innovation in outdoor sports: Technical and social innovation. Society and Leisure, 38:3, 372-382.

Ellis, H.B., Briggs, K.K. \& Philippon, M.J. (2011). Innovation in hip arthroscopy: is hip arthritis preventable in the athlete? Br J Sports Med, 45:253-258.

English, P. (2014). Twitter's diffusion in sports journalism: role models, laggards and followers of the social media innovation. New media \& Society, 18:3, 484-501.

Esson, J. (2015). Escape to victory: Development, youth entrepreneurship and the migration of Ghanaian footballers. Geoforum, 64, 47-55.

Fagerberg, J. (2013). Innovation: A Guide to the Literature in Fagerberg, J., Mowery, D.C. \& Nelson, R.R. (eds.). The Oxford Handbook of Innovation. Oxford: Oxford University Press.

Fredberg, T. \& Piller, F.T. (2011). The paradox of tie strength in customer relationship for innovation: a longitudinal case study in the sports industry. $R \& D$ Management,41:5, 470-484.

Fuller, J., Jawecki, G. \& Muhlbacher, H. (2007). Innovation creation by online basketball communities. Journal of Business Research, 60, 60-71.

Goff, B., McCormick, R. \& Tollison, R. (2002). Racial integration as an innovation: Empicial evidence from sports leagues. American Economic Review, 92(1), 16-26.

Goldsby, M., Kuratko, D. \& Bishop, J. (2005). Entrepreneurship and fitness: an examination of rigourous exercise and goal attainment among small business owners. Journal of Small Business Management, 43(1), 78-92.

Groves, R.M. (2011). New age athletes as social entrepreneurs: proposing a philanthropic paradigm shift and creative use of limited liability company joint ventures. Wake Forest Journal of Business \& Intellectual Property, 11, 212-242.

Hall, C.M. (2006). Urban Entrepreneurship, corporate interests and sports-mega events: the thin policies of competitiveness within the hard outcomes of neoliberalism. Sociological Review, 54(2), 59-70.

Harun, M.T. \& Salamuddin, N. (2013). Applying Elements of Outdoor Education in Teacher Education Innovation. Asian Social Science, vol.9, no. 16: 15-21."

Hartley, J. (2013). Public and Private Features of Innovation. In S.P. Osborme \& L. Brown (eds). Handbook of Innovation in Public Services. Cheltenhamn: Edward Elgar Publishing.

Hayhurst, L.M.C. (2014). The 'Girl Effect' and martial arts: social entrepreneurship and sport, gender and development in Uganda. Gender, Place \& Culture, 21:3, 297-315.

Hienerth, C. (2006). The commercialization of user innovations: The development of the rodeo kayak industry. R and D Management, 36, 273-294.

Hoeber, L., Doherty, A., Hoeber, O. \& Wolfe, R. (2015). The nature of innovation in community sport organizations. European Sport Management Quarterly, 15:5, 518-534.

Hoeber, L. \& Hoeber, O. (2012). Determinants of an innovation process: a case study of technological innovation in a community sport organization. Journal of Sport Management, 26, 213-223.

Hoque, K. (2000). Human Resource Management in the Hotel Industry. Strategy, Innovation and Performance. London: Routledge 
Hunter, G. (2010). Innovation and creativity - 'Strangled' by hierarchical models of evidence? Reflections from innovating in Olympic and Paralympic Sport. Physical Therapy in Sport, 11, 37-38.

Hutchins, B. (2016). "The more things change, the more they stay the same": Path dependency, sports content, and the suppression of innovation in mobile television. Telematics and Informatics, 33, 703-710.

Hyysalo, S. (2009). User innovation and everyday practices: micro-innovation in sports industry development. $R$ \& D Management, 39 (3), 247-258.

Jesson, J.K., Matheson, L. \& Lacey, F.M. (2011). Doing your literature review: traditional and systematic techniques. London: Sage

Jones, O. \& Gatrell, C. (2014). The future of writing and reviewing. International Journal of Management Reviews, vol. 16, issue 3: 249-264.

Johnson RJ (2010). New Innovations in Sports Medicine: Good for the patient or good for the pocketbook? Current Sports Medicine Reports, vol.9, issue 4: 191-193.

Johnston, R.E. \& Bate, J.D. (2013). The Power of Strategy Innovation. A New War of Linking Creativity and Strategic Planning to Discover Great Business Opportunities. New York: AMACOM.

Khromin EV, Kolychev AV, Subbotina SV and Radostev NG (2014). Municipal system innovations in the field of physical culture and sport: adoption and effectiveness. Teoriya I Praktika Fizicheskoy Kultury, issue 12: 82-85.

Lewis, R.W. (2010). Innovation not Invention: A Reply to Peter Swain Regarding the Professionalization of Association Football in England and its Diffusion, Sport in History, 30:3, 475-488.

Liang, L. (2013). Television, technology and creativity in the production of a sports mega event. Media, culture \& society, 35(4), 472-488.

Liebermann, D.G., Katz, L., Hughes, M.D., Barlett, R.M., McClements, J. \& Franks, I.M. (2002). Advances in the application of information technology to sport performance. Journal of Sports Sciences, vol. 20, issue 10, 755-769.

Luthje, C. (2004). Characteristics of innovating users in a consumer goods field. An empirical study of sport-related product consumers. Technovation, 24: 683-695.

Luthje, C., Herstatt, C. \& Von Hippel, E. (2006). User-innovators and 'local' information: The case of mountain biking. Research Policy, 34-6, 951-965.

Marques Miragaia, D.A., Nunes Martins, C.I., Kluka, D.A. \& Havens, A. (2015). Corporate social responsibility, social entrepreneurship and sport programs to develop social capital at community level. Int Rev Public Nonprofit Mark, 12:141-154

McKeown, M. (2008). The truth about innovation. London: Prentice Hall.

Mukhopadhyay, S.C. (2014). Wearable sensors for Human Activity Monitoring: A review. IEEE Sensors Journal, vol 15, issue 3: 1321-1330.

Nevill, A.M. \& Whyte, G.P. (2005). Are there limits to running world records? Medicine and Science in Sports and Exercise, 37, 1785-1788. 
Nevill, A.M., Whyte, G.P., Holder, R.L. \& Peyerbrune, M. (2007). Are there limits to swimming world records? International Journal of Sports Medicine, 28, 1012-1017.

Newell, S. \& Swan, J. (1995). The diffusion of innovation in sport organizations: An evaluative framework. Journal of Sport Management, 9, 318-338.

Nordin, S. \& Svensson, B. (2007). Innovative destination governance. The Swedish ski resort of Åre. The International Journal of Entrepreneurship and Innovation, 8, 53-66.

Pantzar, M. \& Shove, E. (2010). Understanding innovation in practice: A discussion of the production and re-production of Nordic walking. Technology Analysis \& Strategic Management, $22,447-461$.

Parris, D.L., Trolio, M.L., Bouchet, A. \& Peachey, J.W. (2014). Action sports athletes as entrepreneurs: female professional wakeboarders, sponsorship and branding. Sport Management Review, 17, 530-545.

Pill S, Penney D and Swabey K (2012). Rethinking sport teaching in physical education: A case study of research based innovation in teacher education. Australian Journal of Teacher Education, vol. 37 , issue 8: $118-137$

Ratten, V. (2010). The future of sports management: A social responsibility, philanthropy and entrepreneurship perspective. Journal of Management and Organization, vol. 16, issue 4: 488-495.

Ratten, V. (2011a). Sport-based entrepreneurship: towards a new theory of entrepreneurship and sport management. International Entrepreneurship Management Journal, 7: 57-69

Ratten, V. (2011b). 'A social perspective of sports-based entrepreneurship'. International Journal of Entrepreneurship and Small Business, Vol. 12, No. 3, pp.314-326.

Ratten, V. (2011c). 'Social entrepreneurship and innovation in sports', International Journal of Social Entrepreneurship and Innovation, Vol. 1, No. 1, pp.42-54.

Ratten, V. (2012). 'Sports entrepreneurship: towards a conceptualisation', International Journal of Entrepreneurial Venturing, Vol. 4, No. 1, pp.1-18.

Ratten, V. (2015). Athletes as entrepreneurs: the role of social capital and leadership ability. Int. J. Entrepreneurship and Small Business, Vol. 25, No. 4, 442-455.

Ringuet-Riot CJ, Hahn A and James DA (2013). A structured approach for technology innovation in sport. Sports Technology, vol.6, issue 3: 137-149

Ringuet-Riot CJ, Carter S and James DA (2014). Programmed innovation in team sport using needs driven innovation. Procedia Engineering, vol. 72: 817-822.

Rossi, T. \& Rynne, S. (2014). Sport development programmes for Indigenous Australians: innovation, inclusion and development, or a product of 'white guilt'?, Sport in Society, 17:8, 1030-1045

Saint-Martin, J., Sarve, F. \& Terret, T. (2012). Early Alpine mountain bike events. Between sport and tourism economy (1983-1987). Journal of Alpine Research, 100-3

Sanderson, A.R. \& Siegfried, J.J. (2003). Thinking about competitive balance. Journal of Sports Economics, 4, 255-279. 
Slack, T. (1996). From the locker room to the board room: Changing the domain of sport management. Journal of Sport Management, 10, 97-105.

Schleien, S.J. \& Miller, K.D. (2010). Diffusion of innovation: a roadmap for inclusive community recreation services. Research \& Practice for Persons with Severe Disabilities, Vol. 35, No. 4, 93-101

Schumpeter JA (1942). Capitalism, Socialism and Democracy. New York: Haper and Row.

Schumpeter JA (1983). The Theory of Economic Development. An Inquiry into profits, Capital, Credit, Interest and the Business Cycle. New Brunswick: Transaction.

Sheridan, H. (2007). Evaluating Technical and Technological Innovations in Sport - Why Fair Play isn’t enough. Journal of Sport and Social Issues, vol.31(2), 179-194.

Shilbury, D. (2011). Competition: The Heart and Soul of Sport Management. Journal of Sport Management, 26, 1-10.

Shilbury, D., Westerbeek, H., Quick, S. \& Funk, D. (2009). Strategic sport marketing (3rd ed.) Sydney: Allen \& Unwin.

Speed CA and Roberts WO (2011). Innovation in high-performance sports medicine. British Journal of Sports Medicine, vol. 45, issue 12: 949-951.

Sundbo, J. (1998). The Theory of Innovation - Entrepreneurs, Technology and Strategy. Massachusettes: Edward Elgar Publishing.

Stride, C., Williams, J., Moor, D. \& Catley, N. (2015). From sportswear to leisurewear: the evolution of English football league shirt design in the replica kit era. Sport in History, 35:1, 156-194.

Pantzar, M. \& Shove, E. (2010). Understanding innovation in practice: A discussion of the production and re-production of Nordic walking. Technology Analysis \& Strategic Management, $22,447-461$.

Terra, B., Batista, L.A., Cortines Campos, S.R. \& Almeida, M. (2013). Interaction Among Universities, Government and Spin-off Companies in a Brazilian Context to Generate Sports Innovation. Journal of Technology Management \& Innovation, vol.8, issue 2: 93-106.

Thibault, L., Slack, T. \& Hinings, B. (1993). A Framework for the Analysis of Strategy in Nonprofit Sport Organizations. Journal of Sport Management, 7, 25-43.

Tjora, A. (2010). Kvalitative forskningsmetoder i praksis [Qualitative research methods]. Oslo: Gyldendal Akademisk.

Tjønndal, A. (2016a). Innovation and Social Inclusion in Sport. Examples of gender-based inclusion in skateboard. In V.Ratten \& J. Ferreira (eds). Sport Entrepreneurship and Innovation. London: Routledge (in press).

Tjønndal, A. (2016b). Innovation for Inclusion in Sport: A case study of skateboard and gender. Conference paper presented at the $51^{\text {st }}$ World Congress of Sociology of Sport, $9^{\text {th }}$ of June, 2016. Budapest, Hungary.

Trabal P (2008). Resistance to technological innovation in Elite sport. International Review for the Sociology of Sport, vol. 43, issue 3: 313-330.

Tranfield, D., Denyer, D. \& Smart, P. (2003). Towards a Methodology for Developing EvidenceInformed Management Knowledge by Means of Systematic Review. British Journal of Management, vol. 14, issue 3: 207-222. 
Winand, M., Vos, S., Zintz, T. \& Scheerder, J. (2013). Determinants of service innovation: A typology of sports federations. International Journal of Sport Management and Marketing, $13(1), 55-73$.

Yoshida, M., James, J.D. \& Cronin, J.J. (2013). Sport event innovativeness: conceptualization, measurement and its impact on consumer behavior. Sport Management Review, 16: 68-84.

van der Woude, L.H.V., de Groot, S. \& Janssen, T.W.J. (2006). Manual wheelchairs: research and innovation in rehabilitation, sports, daily life and health. Medical Engineering \& Physics 28, 905-915. 